\title{
Effects of Chronic Buspirone Treatment on Nicotine and Concurrent Nicotine + Cocaine Self-Administration
}

\author{
Nancy K Mello*,', Peter A Fivel' and Stephen J Kohut' \\ 'Alcohol and Drug Abuse Research Center, McLean Hospital-Harvard Medical School, Belmont, MA, USA
}

Nicotine dependence and cocaine abuse are major public health problems, and most cocaine abusers also smoke cigarettes. An ideal pharmacotherapy would reduce both cigarette smoking and cocaine abuse. Buspirone (Buspar) is a clinically available, nonbenzodiazepine anxiolytic medication that acts on serotonin and dopamine systems. In preclinical studies, it reduced cocaine selfadministration following both acute and chronic treatment in rhesus monkeys. The present study evaluated the effectiveness of chronic buspirone treatment on self-administration of intravenous (IV) nicotine and IV nicotine + cocaine combinations. Five cocaineexperienced adult rhesus monkeys (Macaca mulatta) were trained to self-administer nicotine or nicotine + cocaine combinations, and food pellets ( I g) during four I-h daily sessions under a second-order schedule of reinforcement (FR 2 (VRI 6:S)). Each nicotine + cocaine combination maintained significantly higher levels of drug self-administration than nicotine or cocaine alone $(P<0.05-0.00 \mathrm{I})$. Buspirone $(0.032-0.56 \mathrm{mg} / \mathrm{kg} / \mathrm{h})$ was administered IV through one lumen of a double-lumen catheter every $20 \mathrm{~min}$ for $23 \mathrm{~h}$ each day, for $7-10$ consecutive days. Each 7-10-day sequence of buspirone treatment was followed by saline-control treatment for at least 3 days until food- and drug-maintained responding returned to baseline. Buspirone dose-dependently reduced responding maintained by nicotine alone $(0.00 \mathrm{I}-0.1 \mathrm{mg} / \mathrm{kg} / \mathrm{inj} ; P<0.0 \mathrm{I})$ and by nicotine $(0.00 \mathrm{I}$ or $0.0032 \mathrm{mg} / \mathrm{kg} / \mathrm{inj})+$ cocaine combinations $(0.0032 \mathrm{mg} / \mathrm{kg} / \mathrm{inj}$; $P<0.05-0.00$ I) with no significant effects on food-maintained responding. We conclude that buspirone selectively attenuates the reinforcing effects of nicotine alone and nicotine + cocaine polydrug combinations in a nonhuman primate model of drug self-administration.

Neuropsychopharmacology (2013) 38, 1264-1275; doi:I0.1038/npp.2013.25; published online 6 February 2013

Keywords: buspirone; nicotine; nicotine addiction; nicotine + cocaine; polydrug abuse model; preclinical studies

\section{INTRODUCTION}

Cigarette smoking is associated with a number of potentially lethal disorders (cancer, cardiac, and pulmonary disease) and causes an estimated 450000 deaths each year (CDC, 2002, 2004, 2005). Cocaine addiction is also a major public health problem, and most cocaine abusers also smoke cigarettes. No uniformly effective medication has been identified to treat either nicotine addiction or cocaine addiction alone, and the persistent use of both drugs in combination presents an even greater challenge for medication-based treatment. We developed a model of simultaneous nicotine + cocaine self-administration in nonhuman primates that should facilitate evaluation of candidate treatment medications. (Mello and Newman, 2011). This combination appeared to enhance the reinforcing effects of these drugs. For example, we found that when minimally reinforcing doses of nicotine and cocaine were

*Correspondence: Dr NK Mello, Alcohol and Drug Abuse Research Center, McLean Hospital- Harvard Medical School, I I 5 Mill Street, Belmont, MA 02478, USA, Tel: + 617855 2746, Fax: + | 617855 2519, E-mail: nmello@mclean.harvard.edu Received 6 November 2012; revised 27 December 2012; accepted 14 January 2013; accepted article preview online 21 January 2013 combined, drug self-administration increased significantly above levels observed when the same dose of nicotine or cocaine alone was available (Mello and Newman, 2011). The nicotine-related enhancement of cocaine's reinforcing effects in rhesus monkeys (Mello and Newman, 2011) is consistent with clinical reports that cocaine-dependent smokers use more cocaine than non-smokers (Budney et al, 1993) and smoke more cigarettes during cocaine use (Roll et al, 1996, 1997). In rhesus monkey, the addition of nicotine to cocaine also shifted the intravenous (IV) cocaine dose-effect curve to the left, but did not increase the progressive ratio breakpoint (Freeman and Woolverton, 2009). In rats, nicotine exposure has been shown to increase cocaine self-administration and reinstate cocaine-seeking behavior (Bechtholt and Mark, 2002; Horger et al, 1992). Moreover, combinations of equally potent doses of nicotine and cocaine produce additive effects on dopamine release from the nucleus accumbens (Gerasimov et al, 2000; Sziraki et al, 1999; Zernig et al, 1997). The current study examines the effects of chronic buspirone treatment on self-administration of nicotine alone and nicotine + cocaine, in a new polydrug model of concurrent cocaine + nicotine self-administration (Mello and Newman, 2011).

Buspirone (Buspar) is a non-benzodiazepine anxiolytic that is approved by the FDA for the treatment of anxiety. 
Buspirone has also been used to facilitate smoking cessation (Henningfield et al, 2005). We recently reported that acute administration of buspirone $(0.1$ or $0.3 \mathrm{mg} / \mathrm{kg}$, IM) selectively reduced IV cocaine self-administration maintained on a fixed-ratio 30 (FR 30) schedule in rhesus monkeys (Bergman et al, 2012). Buspirone produced a downward shift in the cocaine dose-effect curve $(0.003-0.1 \mathrm{mg} / \mathrm{kg} / \mathrm{inj})$ with minimal effects on food-maintained responding (Bergman et al, 2012). These findings were confirmed and extended in a study of the effects of chronic IV buspirone treatment on IV cocaine- and food-maintained responding (Mello et al, 2012). Chronic buspirone treatment (0.32 and $0.56 \mathrm{mg} / \mathrm{kg} / \mathrm{h}$ ) significantly reduced the peak of the cocaine dose-effect curve and shifted the ascending limb of the curve downwards and to the right. These effects were selective for cocaine as food-maintained responding was minimally affected by buspirone treatment.

The mechanisms by which buspirone decreased cocaine self-administration are unclear. Buspirone acts as a $5-\mathrm{HT}_{1 \mathrm{a}}$ partial agonist (Newman-Tancredi et al, 1998; Wong et al, 2007) and also binds to dopamine $\mathrm{D}_{2}, \mathrm{D}_{3}$, and $\mathrm{D}_{4}$ receptors (Bergman et al, 2012; Kula et al, 1994; Tallman et al, 1997). Buspirone functionally antagonized $\mathrm{D}_{3}$ and $\mathrm{D}_{4}$ receptors, and had no agonist activity at these receptor subtypes (Bergman et al, 2012). An emerging literature suggests that $\mathrm{D}_{3}$ antagonists may be an important modulator of the abuse-related effects of both cocaine (see for review Heidbreder et al, 2005; Heidbreder and Newman, 2010; Le Foll et al, 2005a; Newman et al, 2005, 2012) and nicotine (Le Foll et al, 2007a; Pak et al, 2006; Ross et al, 2007). We were unable to locate any preclinical studies of the effects of buspirone on the abuse-related effects of nicotine, but a dopamine $\mathrm{D}_{3}$ receptor antagonist has been shown to attenuate nicotine's behavioral effects under several conditions. For example, the dopamine $\mathrm{D}_{3}$ receptor antagonist SB-277011A (Reavill et al, 2000; Stemp et al, 2000) attenuated nicotine-induced reinstatement (Andreoli et al, 2003; Khaled et al, 2010), nicotine-enhanced electrical brain stimulation (Pak et al, 2006), and nicotine-induced conditioned place preference (Le Foll et al, 2005b; Pak et al, 2006). However, the effects of this $D_{3}$ receptor antagonist on nicotine self-administration have been less consistent, possibly due, in part, to differences in the treatment dose and operant response requirements (Andreoli et al, 2003; Khaled et al, 2010; Ross et al, 2007).

In the present study, we examined the effects of chronic (7-10 days) buspirone treatment on IV drug and foodmaintained responding, using a procedure in which saline or buspirone injections were delivered every $20 \mathrm{~min}$ for $23 \mathrm{~h}$ each day. Buspirone is a relatively short-acting medication with active metabolites that may have different durations of action (Dockens et al, 2006, 2007; Gammans et al, 1986). This procedure was designed to ensure that steady-state levels of the treatment medication and its metabolites were present during the four-drug and food sessions each day (Mello et al, 2012; Negus and Mello, 2003a, b). It is increasingly recognized that evaluation of the chronic effects of candidate medications is important to determine if tolerance develops to acute effects during repeated administration, and if medication effects on the abused drug are sustained through time (Mello, 2005; Mello and Negus, 1996). This is the first report to compare the effects of chronic (7-10 days) buspirone treatment $(0.32$ and $0.56 \mathrm{mg} / \mathrm{kg} / \mathrm{h}$ ) on the self-administration of nicotine alone $(0.001-0.1 \mathrm{mg} / \mathrm{kg} / \mathrm{inj})$, and on combinations of nicotine $(0.001-0.0032 \mathrm{mg} / \mathrm{kg} / \mathrm{inj})+$ cocaine $\quad(0.0032 \mathrm{mg} / \mathrm{kg} / \mathrm{inj})$ in nonhuman primates.

\section{MATERIALS AND METHODS}

\section{Subjects}

Five male rhesus monkeys (Macaca mulatta) that weighed between 6 and $10 \mathrm{~kg}$ were studied. All monkeys had a history of cocaine self-administration. Each day, monkeys received multiple vitamins, fresh fruit and vegetables, and Lab Diet Jumbo Monkey Biscuits (PMI Feeds, St Louis, MO) to supplement a banana-flavored pellet diet, fortified with vitamin C (Formula 4TUR banana flavor, grain-based pellet; Purina Mills Test Diet, Richmond, IN). Food supplements were given twice a day between 0900 and $0930 \mathrm{~h}$, and 1700 and $1730 \mathrm{~h}$. Water was continuously available from an automatic watering system. A 12-h light-dark cycle was in effect (lights on 0700-1900 h), and the experimental chamber was dark during food and drug self-administration sessions.

Animal maintenance and research were conducted in accordance with the guidelines provided by the Institute of Laboratory Animal Resources (ILAR-NRC, 1996) and the NIH Office of Laboratory Animal Welfare. The facility is licensed by the US Department of Agriculture, and protocols were approved by the Institutional Animal Care and Use Committee. Monkeys were observed at least twice every day, and any changes in general activity were noted. In addition, the health of the monkeys was periodically monitored by consultant veterinarians trained in primate medicine. Operant food and drug acquisition procedures provided an opportunity for enrichment and for monkeys to manipulate their environment (Line, 1987). Monkeys had visual, auditory, and olfactory contact with other monkeys throughout the study.

\section{Surgical Procedures}

Double-lumen Silicone rubber catheters (ID 0.028 in, OD 0.088 in; Saint Gobain Performance Plastics, Beaverton, MI) were surgically implanted in the internal or external jugular or femoral vein to permit IV drug self-administration and IV buspirone, or saline administration. All surgical procedures were performed under aseptic conditions. Monkeys were initially sedated with ketamine $(5-10 \mathrm{mg} / \mathrm{kg}$, IM). Atropine $(0.05 \mathrm{mg} / \mathrm{kg})$ SC or IM was administered to reduce salivation. Following insertion of an endotracheal tube, anesthesia was maintained with isofluorane (1-2\% mixed with oxygen). After surgery, monkeys were given procaine penicillin $\mathrm{G}$ at 20000 units/kg, IM twice daily for 5 days, or cephalexin $20 \mathrm{mg} / \mathrm{kg}$, PO twice daily for 5 days. An analgesic dose of buprenorphine $(0.032 \mathrm{mg} / \mathrm{kg}$, IM) and Metacam (meloxicam; $0.1 \mathrm{mg} / \mathrm{kg}, \mathrm{SC}$ ) was administered twice daily for 3 days.

The intravenous catheter exited in the mid-scapular region and was protected by a tether system consisting of a custom-fitted nylon vest connected to a flexible stainlesssteel cable and fluid swivel (Lomir Biomedical, Malone, NY). This flexible tether system permits monkeys to move 
freely. Catheter patency was evaluated periodically by administration of a short-acting barbiturate, methohexital sodium $(4 \mathrm{mg} / \mathrm{kg})$ through the catheter lumen. If muscle tone decreased within $10 \mathrm{~s}$ after drug administration, the catheter was considered patent.

\section{Drug Self-Administration Methods}

Monkeys lived in stainless-steel chambers $(64 \times 64 \times 79 \mathrm{~cm})$ equipped with a custom-designed operant response panel $(28 \times 28 \mathrm{~cm}$ ), a pellet dispenser (Gerbrands Model G5210, Arlington, MA) and two syringe pumps (Model 981210, Harvard Apparatus, South Natick, MA), one for each lumen of the double-lumen catheter. During food self-administration sessions, the response key $(6.4 \times 6.4 \mathrm{~cm})$ on the operant panel was illuminated with a red light. Completion of the response requirement under a FR 2, Variable Ratio 16 (FR 2, (VR 16:S)) schedule resulted in presentation of a 1-s red light beneath the response key. Completion of a second VR16 resulted in delivery of a 1-g banana-flavored pellet (Land O'Lakes Purina Feed, LLC, Richmond, IN). During drug self-administration sessions, the response key was illuminated with a green light, and completion of the response requirement under an FR 2, (VR 16:S) schedule resulted in delivery of $0.1 \mathrm{ml}$ of saline or a drug solution over $1 \mathrm{~s}$ through one lumen of the double-lumen catheter. A 10-s time-out followed delivery of each drug or saline injection, or food pellet, during which stimulus lights remained off, and responding had no scheduled consequences. If 25 food pellets or 20 injections were delivered before the end of the 1-h session, then all stimulus lights were turned off, and responding had no scheduled consequences for the remainder of that session. Thus, a monkey could earn a maximum of 100 food pellets per day and 80 drug or saline injections per day in four daily-food and four daily-drug self-administration sessions. The four daily-food self-administration sessions began at 1100, 1500, 1900 , and $0600 \mathrm{~h}$ the next morning, and the four daily-drug self-administration sessions began at 1200,1600, 2000, and $0700 \mathrm{~h}$ the next morning. Room lights were off during all experimental sessions. Schedules of reinforcement were programmed with custom-designed software, and IBMcompatible computers and interface systems (Med Associates, St Albans, VT). Additional details of this apparatus have been described previously (Mello et al, 1995). Drug concentrations were varied by computer-controlled changes in pump infusion duration (Fivel, 2011).

Training procedure. Monkeys were initially trained to self-administer banana-flavored food pellets and cocaine $(0.1 \mathrm{mg} / \mathrm{kg} / \mathrm{inj})$. Once cocaine-maintained responding occurred reliably, the unit dose was reduced to 0.01 or $0.032 \mathrm{mg} / \mathrm{kg}$ to limit the disruptive effects of each IV cocaine injection, and to facilitate higher levels of IV self-administration behavior throughout the session. Extinction training consisted of sessions in which saline was substituted for $0.032 \mathrm{mg} / \mathrm{kg}$ IV cocaine. Once saline extinction was reliable, drug dose-effect curves were determined over a dose range of $0.001-0.10 \mathrm{mg} / \mathrm{kg} / \mathrm{inj}$ IV nicotine. Combinations of doses on the ascending limb for nicotine with a threshold dose of cocaine $(0.0032 \mathrm{mg} / \mathrm{kg} / \mathrm{inj})$ were also tested. Saline and different doses of cocaine + nicotine were presented in an irregular order.

Drug dose-effect curve determinations. Training continued until monkeys met the following criteria for stable food and cocaine self-administration under the FR 2 (VR16:S) schedule of reinforcement: (1) three consecutive days during which the number of drug injections per day varied by no more than $20 \%$ of the 3-day mean, with no upward or downward trend, and (2), the mean number of food pellets and injections delivered per day was equal to or greater than 60. Once responding was stable, self-administration of saline, nicotine $(0.001-0.10 \mathrm{mg} / \mathrm{kg} / \mathrm{inj})$, and combinations of cocaine $(0.0032 \mathrm{mg} / \mathrm{kg} / \mathrm{inj})+$ nicotine $(0.001-0.0032 \mathrm{mg} / \mathrm{kg} / \mathrm{inj})$ were studied. Each dose was substituted for a minimum of 7 days and until responding was stable according to the above criteria, or for a maximum of 10 days. Following each substitution test, monkeys were returned to the maintenance dose of cocaine, $0.01 \mathrm{mg} / \mathrm{kg} / \mathrm{inj}$, for at least 3 days and until responding was stable, to ensure reliable baseline responding before the subsequent substitution test. In one exception, one monkey was maintained on $0.032 \mathrm{mg} / \mathrm{kg} / \mathrm{inj}$ cocaine before being tested with a combination of cocaine $0.0032+$ nicotine $0.001 \mathrm{mg} / \mathrm{kg} / \mathrm{inj}$ and a combination of cocaine $0.0032+$ nicotine $0.0032 \mathrm{mg} / \mathrm{kg} / \mathrm{inj}$. The drug doses were presented in an irregular order that differed for each monkey.

Buspirone treatment procedures. Buspirone doses were selected on the basis of previous reports of buspirone's effects on cocaine self-administration (Bergman et al, 2012; Gold and Balster, 1992; Mello et al, 2012). The effects of buspirone $(0.1,0.32$, and $0.56 \mathrm{mg} / \mathrm{kg} / \mathrm{h})$ on the ascending limb of the nicotine or cocaine + nicotine dose-effect curve were studied first, to determine which doses of buspirone were most effective, and to monitor possible side effects. Subsequently, the most effective doses of buspirone were tested on the nicotine dose-effect curve and on cocaine + nicotine combinations. Procedures for evaluating the effects of buspirone on the reinforcing effects of nicotine, and combinations of cocaine + nicotine were similar to those used in our previous studies of the effects of chronic buspirone treatment on cocaine self-administration (Mello et al, 2012). Saline or a dose of buspirone was administered through one lumen of a double-lumen catheter every $20 \mathrm{~min}$ for $23 \mathrm{~h}$ each day. The total injection volume delivered was $6.9 \mathrm{ml}$ in 69 injections. This procedure was developed to ensure that relatively short-acting drugs would be continuously present during the test sessions (Negus and Mello, 2003a, b). Each treatment dose was studied for 7-10 days until responding was stable according to the criteria described earlier. Successive buspirone doses were separated by an interval of saline treatment until drug- and food-maintained responding returned to baseline levels. The saline treatment interval was used to prevent any carryover effects from the preceding treatment condition.

Data analysis. The primary dependent variables were the total number of drug or saline injections, and food pellets earned per day. Response rate, defined as the total number of responses divided by the total session time 
minus time-outs, was also calculated. The number of injections self-administered and response rates during the last 3 days of each treatment condition were averaged for statistical analysis. Repeated measures analysis of variance (ANOVA) with factors of buspirone treatment, and nicotine dose was used to determine buspirone's effect on nicotine self-administration, food-maintained responding, and response rates. One-way ANOVA for repeated measures for saline and buspirone treatment was also used to determine which doses of nicotine maintained significantly more self-administration than saline injection levels. One-way ANOVA was used to determine buspirone's effects on self-administration of cocaine + nicotine combinations and food-maintained responding. A significant ANOVA $(P<0.05)$ was followed by Dunnett's post-hoc tests. To determine whether the number of injections earned or rate of responding with cocaine + nicotine combinations were significantly higher than either cocaine or nicotine alone, one-way ANOVA with Fisher's LSD post-hoc tests were used. All statistical procedures and figures were drawn using GraphPad Prism v. 6.0.

Drugs. Cocaine $\mathrm{HCl}$ was provided by the National Institute on Drug Abuse (Rockville, MD) and prepared in sterile saline $(0.9 \%)$. Nicotine hydrogen tartrate was obtained commercially (Sigma-Aldrich, St Louis, MO) and solubilized in sterile water buffered with $\mathrm{NaOH}$ to achieve a $\mathrm{pH}$ of 6-7. Self-administered drugs were sterile-filtered with a $22-\mu \mathrm{m}$ syringe-driven filter. The cocaine + nicotine combinations were combined in the same syringe. Cocaine doses are expressed as the salt form, nicotine doses are expressed as the base.

\section{RESULTS}

\section{Buspirone's Effects on Nicotine and Food Self- administration and Response Rates}

During saline-control treatment, the peak of the nicotine dose-effect curve was at a dose of $0.0032 \mathrm{mg} / \mathrm{kg} / \mathrm{inj}$ and monkeys took an average of $49.9 \pm 9$ injections/day (Figure 1). Nicotine injections decreased to an average of $14 \pm 3.57$ at the highest unit dose $(0.10 \mathrm{mg} / \mathrm{kg} / \mathrm{inj})$. Buspirone dose-dependently decreased nicotine self-administration over the dose range, that maintained the highest number of nicotine injections during saline treatment (0.001-0.01 mg/kg/inj). Buspirone $(0.32 \mathrm{mg} / \mathrm{kg} / \mathrm{h})$ significantly reduced nicotine-maintained responding $(0.01 \mathrm{mg} /$ $\mathrm{kg} / \mathrm{inj}$ ) from $43.9 \pm 7.4$ injections during saline-control treatment to $18 \pm 8.5$ injections $(P<0.05)$. Other doses of nicotine did not change significantly from baseline during buspirone treatment. A higher dose of buspirone $(0.56$ $\mathrm{mg} / \mathrm{kg} / \mathrm{h}$ ) also decreased the nicotine dose-effect curve to saline self-administration levels. The peak of the nicotine dose-effect curve decreased to $25 \pm 9$ injections per day $(P<0.05)$. Lower and higher nicotine doses were equivalent to or below saline self-administration levels. Food-maintained responding was unchanged by $0.32 \mathrm{mg} / \mathrm{kg} / \mathrm{h}$ buspirone. Small but non-significant decreases in food-maintained responding occurred during treatment with $0.56 \mathrm{mg} / \mathrm{kg} / \mathrm{h}$ buspirone. Analysis of response rates showed a similar pattern for both nicotine and food-maintained responding.

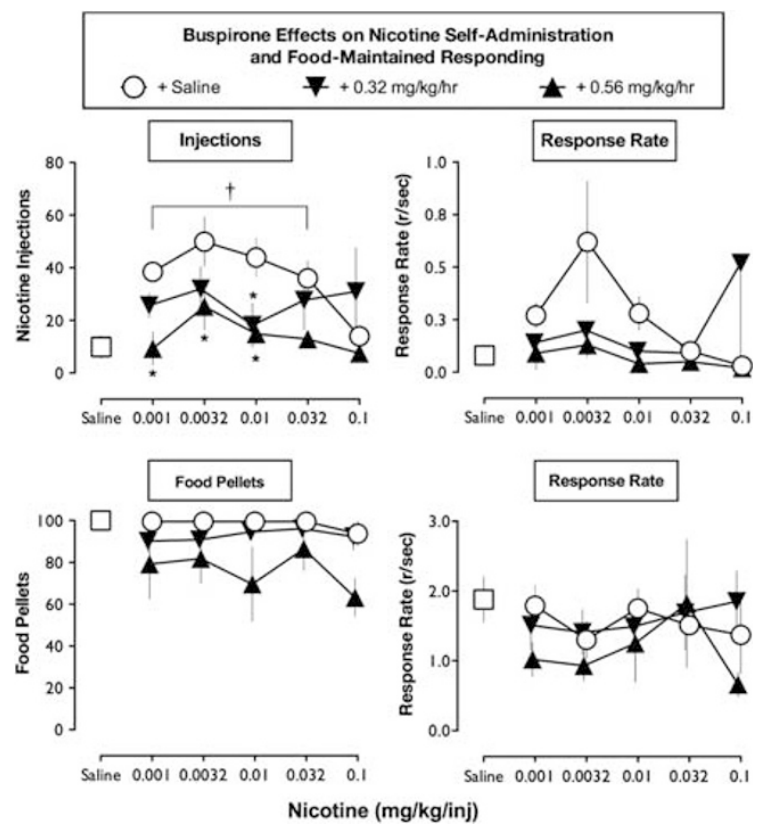

Figure I The effects of chronic treatment with buspirone or saline on nicotine- and food-maintained responding and response rates. Dose-effect curves for nicotine self-administration $(0.001-0.10 \mathrm{mg} / \mathrm{kg} / \mathrm{inj})$ are shown in the top left panel for the group of monkeys. The unit doses of nicotine are shown on the abscissae, and the number of injections per day is shown on the left ordinate. The top right panel shows rate of responding for nicotine on the left ordinate. Points above 'Saline' show data from saline treatment sessions when saline was available for self-administration. Nicotine selfadministration during saline treatment is shown as open circles. Nicotine selfadministration during treatment with buspirone is shown as filled triangles $(0.32$ and $0.56 \mathrm{mg} / \mathrm{kg} / \mathrm{h})$. Food-maintained responding during saline treatment and saline or nicotine self-administration is shown as open circles in the bottom panel. Rate of responding for food pellets is shown in the bottom right panel. Food-maintained responding during treatment with buspirone is shown as filled triangles $(0.32$ and $0.56 \mathrm{mg} / \mathrm{kg} / \mathrm{h})$. Each data point for saline and $0.00 \mathrm{I}-0.10 \mathrm{mg} / \mathrm{kg} / \mathrm{inj}$ nicotine reflects the mean \pm SEM of the last 3 days of a 7-10 day treatment in four monkeys. Repeated measures analysis of variance (ANOVA) analysis of nicotine injections indicated a significant main effect of buspirone treatment $\left(F_{2,6}=\mid I .09 ; P<0.01\right)$ but not nicotine dose $\left(F_{4,12}=2.54 ; \quad P=0.095\right)$. The buspirone treatment $X$ nicotine dose interaction also was not significant $\left(F_{8,24}=1.268 ; P=0.315\right)$. Dunnett's post-hoc tests comparing buspirone with saline-control treatment indicated that $0.32 \mathrm{mg} / \mathrm{kg} / \mathrm{h}$ buspirone significantly reduced nicotine self-administration at doses of $0.01 \mathrm{mg} / \mathrm{kg} / \mathrm{inj}(P<0.05)$ and $0.56 \mathrm{mg} / \mathrm{kg} / \mathrm{h}$ buspirone treatment significantly reduced nicotine self-administration at $0.001,0.0032$, and $0.01 \mathrm{mg} / \mathrm{kg} / \mathrm{inj}$ (all $P<0.05$ ). One-way ANOVA for repeated measures found a significant effect of nicotine dose during saline treatment $\left(F_{5.15}=9.137 ; P<0.00 I\right)$ but not for $0.32\left(F_{5.15}=0.914 ; P=0.498\right)$ or $0.56 \mathrm{mg} / \mathrm{kg} / \mathrm{h}\left(F_{5,15}=1.596 ; P=0.22 \mathrm{I}\right)$ buspirone treatment. Dunnet's posthoc tests found that the number of injections earned when $0.001,0.0032$, 0.01 , and $0.032 \mathrm{mg} / \mathrm{kg} / \mathrm{inj}$ nicotine was available under saline-control treatment was significantly higher than saline self-administration (all $P<0.01$ ). Repeated measures ANOVA analysis of rate of responding for nicotine during saline or buspirone treatment showed a main effect of Buspirone Treatment $\left(F_{2,6}=6.082 ; P<0.05\right)$ but no main effect of nicotine dose $\left(F_{4,12}=1.276 ; P=0.333\right)$ or interaction $\left(F_{8,24}=1.297 ; P=0.292\right)$. Repeated measures ANOVA analysis of food pellets earned found no significant main effects of buspirone treatment $\left(F_{2,6}=3.289 ; P=0.109\right)$ or nicotine dose $\left(F_{4,12}=1.534 ; P=0.254\right)$, or the buspirone treatment $x$ nicotine dose interaction $\left(F_{8,24}=1.537 ; P=0.197\right)$. The ANOVA analysis of response rate for food found no main effect of Buspirone Treatment $\left(F_{2,6}=2.308 ; P=0.181\right)$ or Nicotine Dose $\left(F_{4,12}=1.249 ; P=0.342\right)$, and no significant interaction $\left(F_{8,24}=0.741 ; P=0.656\right)$. Asterisks indicate data points that were significantly lower than during saline-control treatment. A dagger indicates doses of nicotine under saline-control treatment that were significantly higher than saline self-administration. 


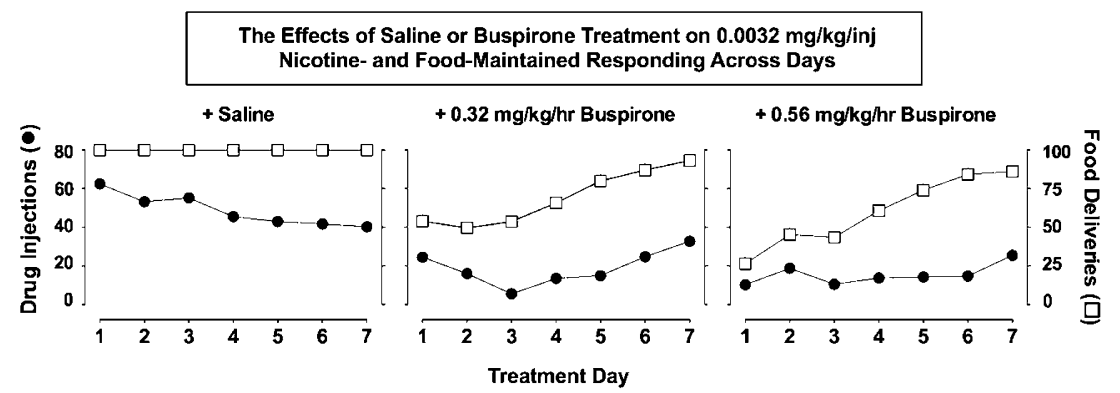

Figure 2 Daily effects of saline or buspirone on the peak reinforcing dose of nicotine and food-maintained responding. Abscissae: consecutive days in each treatment condition; Ordinates: left ordinate, number of drug injections per day (closed circles); right ordinate, number of food pellets delivered per day (open squares). Treatment with saline and each of two doses of buspirone are shown above each 7-day block. Each data point is the average (+ SEM) of four or five monkeys.

\section{Daily Effects of Buspirone on Nicotine and Food Self-Administration}

The effects of saline and buspirone $(0.32$ and $0.56 \mathrm{mg} / \mathrm{kg} / \mathrm{h})$ on the peak reinforcing dose of nicotine $(0.0032 \mathrm{mg} / \mathrm{kg} / \mathrm{inj})$ and food-maintained responding are shown for 7 consecutive days (Figure 2). Each 7- to 10-day sequence of buspirone administration decreased nicotine self-administration on the first day of treatment, and this decrease was sustained throughout the treatment period. Food-maintained responding was initially decreased, but returned towards baseline levels within 5-7 days.

\section{Comparison of the Reinforcing Effects of Nicotine + Cocaine Combinations with Nicotine and Cocaine Alone}

Each nicotine + cocaine combination maintained significantly higher levels of drug self-administration than the same doses of cocaine and nicotine alone $(P<0.05$; Figure 3$)$. Rates of drug-maintained responding also were significantly higher for nicotine + cocaine self-administration than for the same doses of cocaine alone and nicotine alone $(P<0.05)$.

Peak rate of responding for a low dose of cocaine alone averaged $0.51 \pm 0.25$ responses per second. Peak response rate for low doses of nicotine alone averaged $0.27 \pm 0.06$ and $0.62 \pm 0.29$ responses per second, whereas peak response rate for nicotine + cocaine combinations averaged $1.28 \pm 0.30$ and $1.15 \pm 0.29$ responses per second. These rates are slightly lower than that reported for squirrel monkeys working for $0.03 \mathrm{mg} / \mathrm{kg} / \mathrm{inj}$ nicotine on a secondorder fixed ratio, fixed interval schedule (Goldberg et al, 1981). Squirrel monkeys averaged between 0.81 and 1.58 responses per second (Goldberg et al, 1981). On a fixed ratio schedule (FR 10, to $60 \mathrm{~s}$ ), squirrel monkeys responded for nicotine at $0.15 \pm 0.04$ responses per second, whereas saline maintained responding at $0.01 \pm 0.001$ responses per second (Le Foll et al, 2007b). However, differences in species, operant manipulanda, schedules of reinforcement, the unit dose of nicotine, and rate of infusion limit comparisons with previous studies.

\section{Buspirone's Effects on Self-administration of Nicotine + Cocaine Combinations}

A combination of cocaine $(0.0032 \mathrm{mg} / \mathrm{kg} / \mathrm{inj})+$ nicotine $(0.001 \mathrm{mg} / \mathrm{kg} / \mathrm{inj})$ maintained high levels of responding during saline-control treatment $(73.3 \pm 3.9)$ without disrupting food-maintained responding (Figure 4). Low doses of buspirone $(0.032$ and $0.1 \mathrm{mg} / \mathrm{kg} / \mathrm{h})$ did not decrease drug self-administration significantly and had no effect on food-maintained responding. Buspirone $(0.32 \mathrm{mg} / \mathrm{kg} / \mathrm{h})$ decreased drug self-administration by $50 \% \quad(P<0.01)$, whereas food-maintained responding decreased by $11 \%$ compared with control levels. The highest dose of buspirone studied $(0.56 \mathrm{mg} / \mathrm{kg} / \mathrm{h})$ decreased drug self-administration by $85 \% \quad(P<0.0001)$. Food-maintained responding decreased by $32 \%$, but this was not statistically significant. Under these conditions, buspirone dose-dependently decreased cocaine + nicotine self-administration with minimal effects on food-maintained responding. Analysis of response rates showed a parallel effect of buspirone on drug and food-maintained responding.

Similarly, a combination of cocaine $(0.0032 \mathrm{mg} / \mathrm{kg} / \mathrm{inj})+$ nicotine $(0.0032 \mathrm{mg} / \mathrm{kg} / \mathrm{inj})$ also maintained high levels of responding during saline-control treatment $(77.5 \pm 1.6 \mathrm{inj}$ per day) with no effect on food-maintained responding. Chronic buspirone treatment $(0.1-0.56 \mathrm{mg} / \mathrm{kg} / \mathrm{h})$ dosedependently and significantly decreased cocaine + nicotine self-administration $(P<0.0001)$. Daily drug-maintained responding decreased by 25,66 , and $91 \%$ from the saline treatment baseline as buspirone doses increased from 0.1 to $0.56 \mathrm{mg} / \mathrm{kg} / \mathrm{h}$. Food-maintained responding was unaffected at buspirone doses of 0.1 and $0.32 \mathrm{mg} / \mathrm{kg} / \mathrm{h}$, and decreased non-significantly by $24 \%$ at a buspirone dose of 0.56 $\mathrm{mg} / \mathrm{kg} / \mathrm{h}$. Parallel decreases in response rates were observed.

\section{Daily Effects of Buspirone on Self-Administration of Nicotine + Cocaine Combinations and Food-Maintained Responding}

During saline-control treatment, each drug combination maintained stable levels of drug self-administration and food-maintained responding (Figure 5). Buspirone dosedependently decreased self-administration of each cocaine + nicotine combination. The greatest decrease from the saline-control baseline occurred during treatment with $0.56 \mathrm{mg} / \mathrm{kg} / \mathrm{h}$ buspirone. A buspirone-related decrease in drug-maintained responding usually occurred on the first day of treatment and was sustained across 7 days. Foodmaintained responding also decreased initially during treatment with 0.32 and $0.56 \mathrm{mg} / \mathrm{kg} / \mathrm{h}$ buspirone, but these decreases were transient and recovered to near control levels by the end of treatment. 

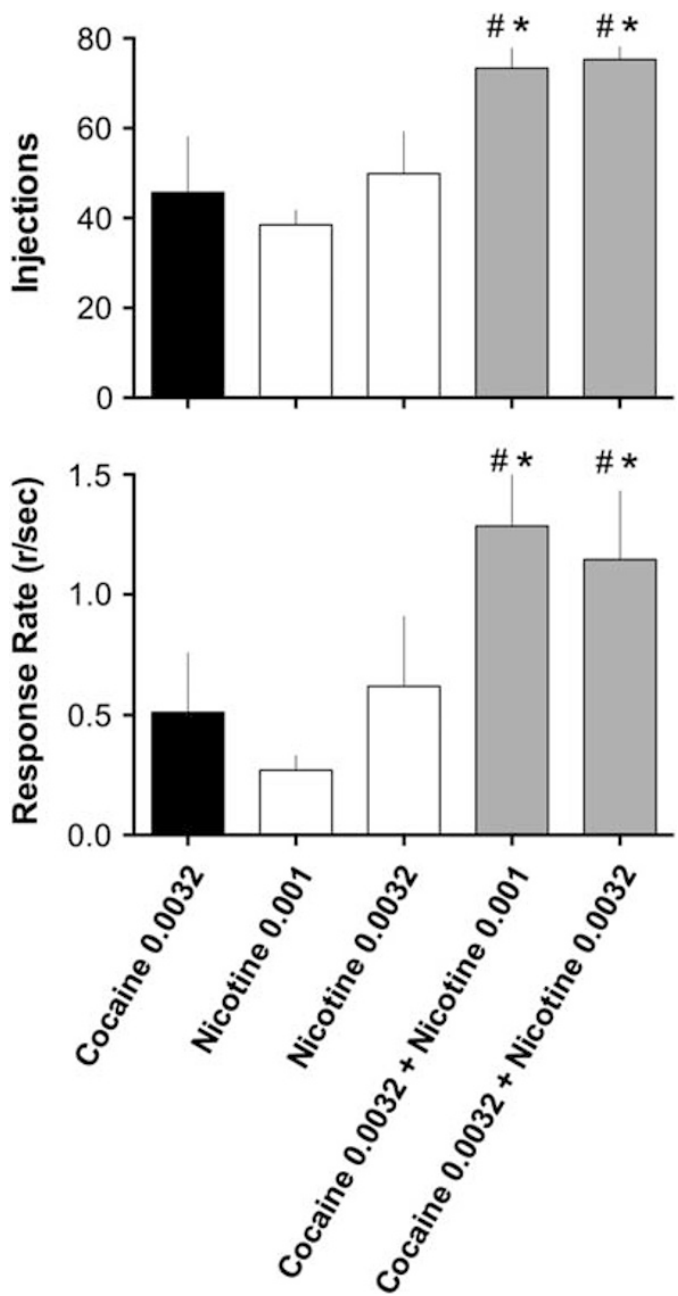

Figure 3 Comparison of the number of injections per day (top panel) and rate of responding (bottom panel) for cocaine and nicotine alone with cocaine + nicotine in combination during saline treatment. Abscissa: doses of cocaine $(0.0032 \mathrm{mg} / \mathrm{kg} / \mathrm{inj})$, nicotine $(0.00 \mathrm{I}$ and $0.0032 \mathrm{mg} / \mathrm{kg} / \mathrm{inj})$, and cocaine $(0.0032 \mathrm{mg} / \mathrm{kg} / \mathrm{inj})+$ nicotine $(0.00 \mathrm{l}$ or $0.0032 \mathrm{mg} / \mathrm{kg} / \mathrm{inj})$ in combination. Ordinate (top): number of drug injections per day during saline treatment. Ordinate (bottom): rate of responding in responses per second during saline treatment. Each data point is the average (+ SEM) of 5 monkeys during the last 3 days of each drug condition. One-way repeated measures analysis of variance (ANOVA) with Fisher's LSD posthoc tests were used to determine whether self-administration of the cocaine + nicotine combinations was significantly higher than the same doses of nicotine or cocaine alone as measured by number of injections per day and rate of responding. Post-hoc tests compared cocaine $(0.0032 \mathrm{mg} /$ $\mathrm{kg} / \mathrm{inj})$ alone and each dose of nicotine alone with the cocaine + nicotine combination, in which that dose of nicotine was present. The ANOVA found a significant main effect of reinforcer $\left(F_{4,16}=5.195 ; P<0.01\right)$. Posthoc tests found that monkeys self-administered significantly more $0.0032 \mathrm{mg} / \mathrm{kg} / \mathrm{inj}$ cocaine when it was combined with either dose of nicotine compared with that cocaine dose alone (both $P<0.05$ ). Further, both cocaine + nicotine combinations were self-administered significantly more than either nicotine dose alone (combination vs $0.00 \mathrm{I} \mathrm{mg} / \mathrm{kg} / \mathrm{inj}$ nicotine alone, $P<0.0 \mathrm{I}$; combination vs $0.0032 \mathrm{mg} / \mathrm{gk} / \mathrm{inj}$ nicotine alone, $P<0.05)$. Similarly, in the bottom panel, ANOVA found a significant main effect of reinforcer $\left(F_{4.16}=8.578 ; P<0.00 \mathrm{I}\right)$. Post-hoc tests revealed that rate of responding for both cocaine + nicotine combinations were significantly higher than for cocaine alone (both $P<0.05$ ) or either dose of nicotine alone (vs $0.00 \mathrm{l} \mathrm{mg/kg/inj} \mathrm{nicotine} P<0.00$ I; vs $0.0032 \mathrm{mg} / \mathrm{kg} / \mathrm{inj}$ nicotine $P<0.0 \mathrm{I}$ ). Asterisks indicate points that were significantly greater than nicotine alone and pound signs indicate points that were also significantly greater than cocaine alone as described above.
Sedation Ratings During Buspirone Treatment

Sedation ratings on a four-point scale (0-3) were recorded by a trained observer immediately following the drug selfadministration session conducted between 1200 and $1300 \mathrm{~h}$ each day (Table 1). This scale was adapted from one designed to measure sedation and prolactin following administration of a dynorphin analog (Butelman et al, 1999). Table 1 shows that during $0.32 \mathrm{mg} / \mathrm{kg} / \mathrm{h}$ buspirone treatment, only one rating exceeded 1 , indicating mild sedation. During $0.56 \mathrm{mg} / \mathrm{kg} / \mathrm{h}$ buspirone treatment, mild sedation was observed during the first 3 days of treatment, but monkeys were less sedated during the last 3 days of treatment. Cocaine data are from Mello et al (2012). Notice the similarity in sedation scores across drugs. Buspirone did not appear to induce significant sedation that influenced nicotine or cocaine self-administration.

\section{DISCUSSION}

This is the first report of the effects of chronic buspirone treatment on the reinforcing effects of nicotine alone, and a combination of nicotine + cocaine in rhesus monkeys. Our major findings were that chronic buspirone treatment dosedependently reduced self-administration of nicotine alone and combinations of nicotine + cocaine. These data parallel our recent report that chronic buspirone treatment significantly reduced cocaine self-administration studied under the same behavioral conditions (Mello et al, 2012). Another major finding was that combining low, minimally reinforcing doses of nicotine, and cocaine increased drug self-administration significantly above levels maintained by the same dose of each drug alone. These data confirm and extend our earlier report of the behavioral effects of lowdose nicotine + cocaine combinations in rhesus monkeys (Mello and Newman, 2011). Taken together, these findings indicate that this polydrug model will be useful for the evaluation of treatment medications that may attenuate dual addiction to nicotine and cocaine. The relation of these data to the abuse-related similarities between nicotine and cocaine are described below. The possible role of buspirone's dopamine $\mathrm{D}_{3}$ and $\mathrm{D}_{4}$ receptor antagonist actions (Bergman et al, 2012; Newman et al, 2012) is described in the context of recent studies of the effects of selective dopamine $\mathrm{D}_{3}$ and $\mathrm{D}_{4}$ receptor compounds on the abuserelated effects of nicotine.

\section{Buspirone's Effects on Nicotine and Nicotine + Cocaine Self-Administration}

Buspirone significantly and selectively reduced self-administration of nicotine and nicotine + cocaine combinations. These data are consistent with our previous reports that acute and chronic buspirone treatment, over the same dose range, significantly and selectively reduced cocaine selfadministration by rhesus monkeys (Bergman et al, 2012; Mello et al, 2012). Chronic buspirone treatment shifted the cocaine dose-effect curve downwards and to the right, and significantly reduced the peak reinforcing dose of cocaine $(P<0.05$; Mello et al, 2012). In both studies, buspirone did not significantly alter concurrent food-maintained respond- 

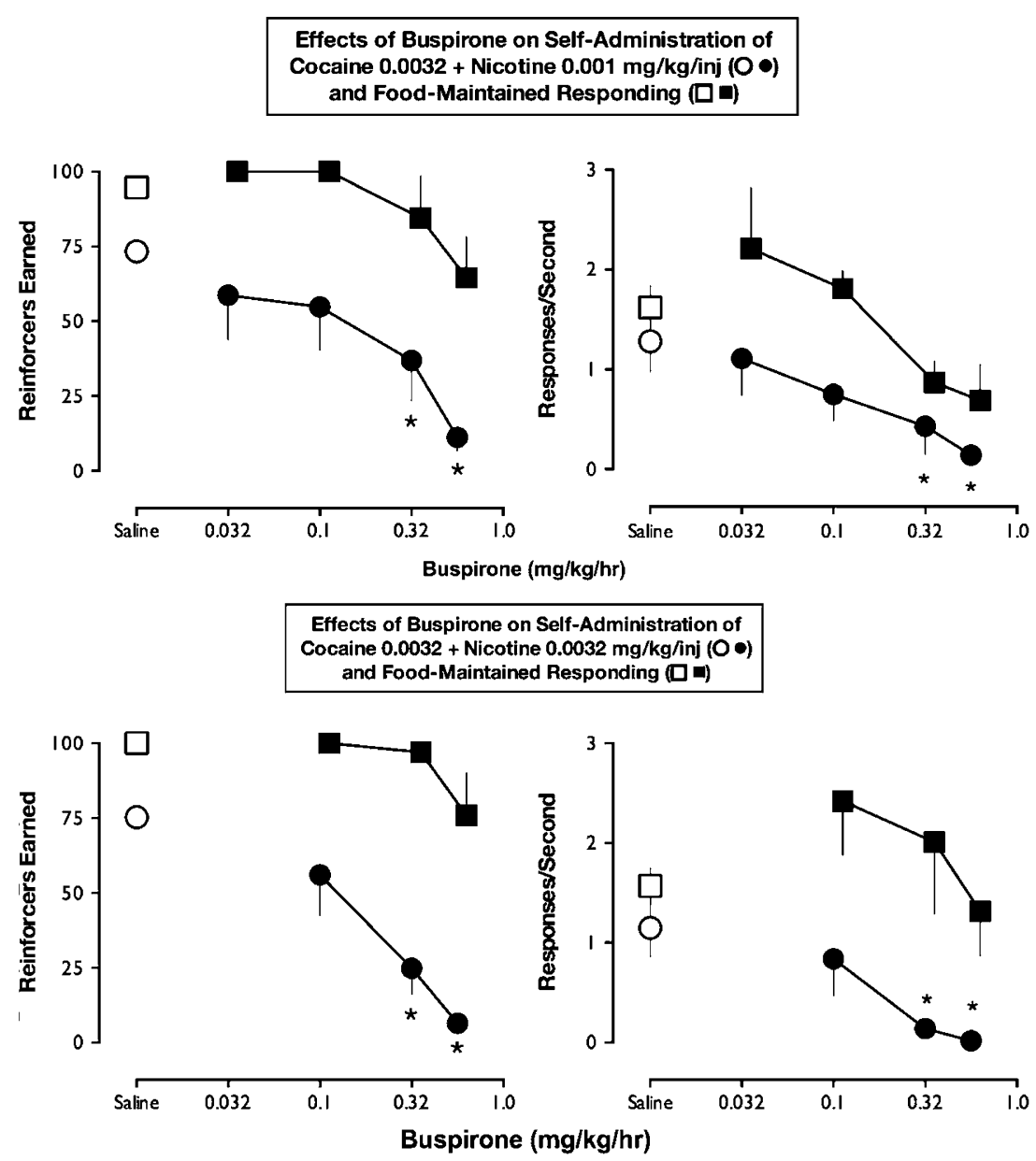

Figure 4 The effects of buspirone on self-administration of cocaine $(0.0032 \mathrm{mg} / \mathrm{kg} / \mathrm{inj})+$ nicotine $(0.00 \mathrm{I}$ or $0.0032 \mathrm{mg} / \mathrm{kg} / \mathrm{inj})$, food-maintained responding and response rates. Abscissae: saline or ascending doses of buspirone $(\mathrm{mg} / \mathrm{kg} / \mathrm{h})$. Left ordinates: total drug injections (open and closed circles) and food pellets earned during the last 3 days of each treatment condition (open and closed squares). Points above 'Saline' indicate reinforcers earned during salinecontrol treatment. Right ordinates: response rates during each condition. Each data point is the average of 5 monkeys. The ANOVA analysis for repeated measures indicated a significant effect of buspirone treatment on drug injections earned and rate of responding at each dose combination (all F $>4.624$; $P<0.0 \mathrm{I}-0.000 \mathrm{I}$ ). Asterisks indicate the unit doses of cocaine + nicotine that were significantly different during buspirone treatment than the corresponding doses during saline-control treatment $(P<0.05-0.00 I)$. There were no significant effects of buspirone on food pellets earned at any dose (all $\mathrm{F}<2.582$; $P=0.07-0.09)$. Rate of responding for food pellets was slightly but significantly decreased when cocaine + the lower nicotine dose (0.00 I mg/kg/inj) was available $\left(F_{4,16}=4.353 ; P=0.01\right)$, but not when cocaine + the higher nicotine dose $(0.0032 \mathrm{mg} / \mathrm{kg} / \mathrm{inj})$ was combined with cocaine $\left(F_{3,12}=1.473 ; P=0.272\right)$. However, Dunnett's post-hoc tests revealed that buspirone did not change rate of responding for food relative to saline at any dose $(P=0.14-0.97)$.

ing. These data indicate that the sustained decreases in nicotine and nicotine + cocaine self-administration reflected the effects of buspirone treatment and not a general disruption of operant responding. The observed decreases in nicotine and nicotine + cocaine self-administration during buspirone treatment were not associated with significant sedative effects. All monkeys resumed drug self-administration at baseline levels after buspirone treatment was discontinued. This indicates that IV catheters were patent, and catheter blockade did not account for the observed decreases in drug-maintained responding. The same monkeys were studied as their own control across successive saline and buspirone treatment conditions. Importantly, this is the first study of nicotine and nicotine + cocaine self-administration in which buspirone was administered every $20 \mathrm{~min}$ for $23 \mathrm{~h}$ each day to ensure that treatment doses were present during each of the four daily drug and food self-administration sessions.
As in our previous studies of the effects of buspirone treatment on cocaine self-administration, the effective buspirone doses were higher than those used clinically for the treatment of anxiety (Bergman et al, 2012; Mello et al, 2012). However, differences in the route (oral $v s$ IV) and the rate (bolus $v s$ three injections per hour) of buspirone administration in humans and in rhesus monkeys make it difficult to compare doses. In a Phase 1 clinical trial entitled 'Evaluation of buspirone for relapse-prevention in adults with cocaine dependence: An efficacy trial conducted in the real world,' a daily dose of $60 \mathrm{mg}$ of buspirone is planned (Winhusen et al, 2012). In our previous study, we reported that after $48 \mathrm{~h}$ of $0.32 \mathrm{mg} / \mathrm{kg} / \mathrm{h}$ buspirone, plasma levels ranged between 39-74 ng/ml (Mello et al, 2012). These doses of buspirone were well tolerated. Chronic buspirone treatment was not associated with any adverse behavioral or medical consequences, and there were no significant changes in blood chemistry assessments at 3, 4, 10 or 14 


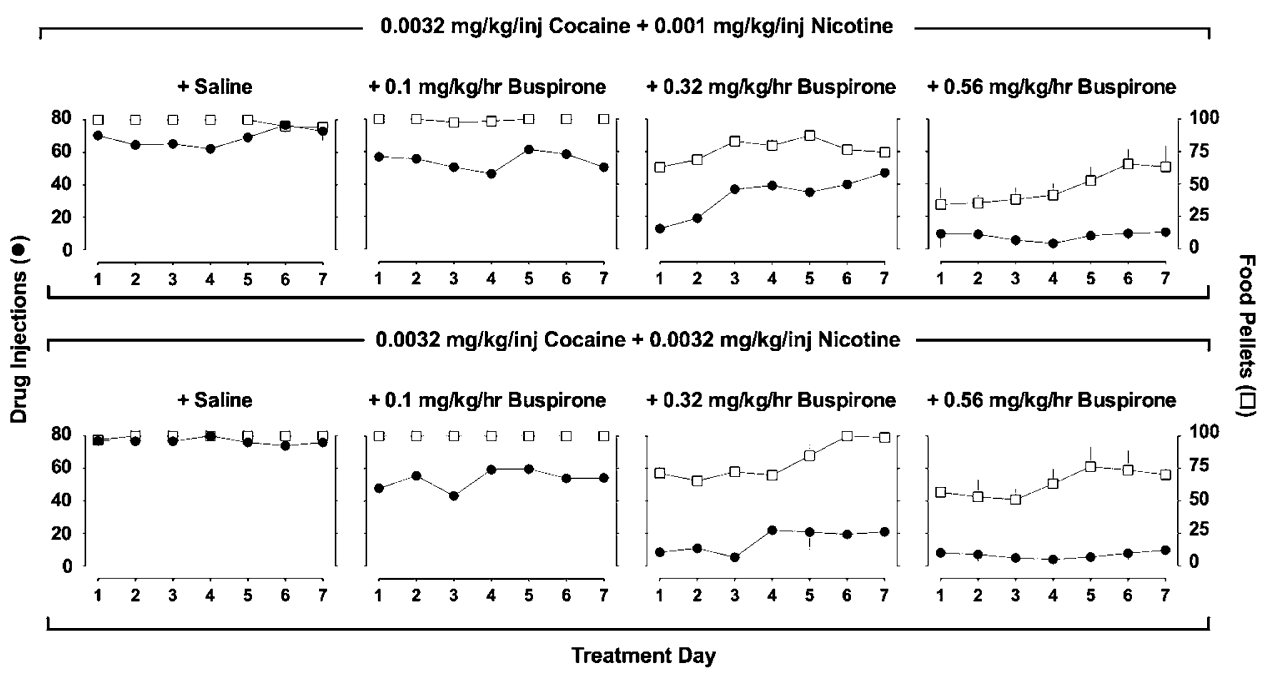

Figure 5 Daily effects of saline or buspirone on cocaine + nicotine combinations, and food-maintained responding. Abscissae: consecutive days in each treatment condition. Ordinates: left ordinate, number of drug injections per day (closed circles); right ordinate, number of food pellets delivered per day (open squares). The dose of cocaine + nicotine available for self-administration is shown above each row. Treatment with saline and each of three doses of buspirone are shown above each 7-day block. Each data point is the average ( + SEM) of five monkeys.

days after discontinuation of buspirone treatment (Mello et al, 2012).

\section{Similarities between the Abuse-Related Effects of Nicotine and Cocaine}

The concordance between buspirone's effects on nicotine in the present study and cocaine self-administration in our earlier studies (Bergman et al, 2012; Mello et al, 2012) is consistent with the several similarities in the neurobiology of nicotine and cocaine. Both drugs activate the mesolimbic dopamine system and enhance extracellular dopamine levels. However, cocaine and nicotine each increase dopamine levels by different mechanisms. Cocaine blocks dopamine reuptake by the dopamine transporter (Kuhar et al, 1991; Ritz et al, 1987, 1988), whereas nicotine induces dopamine release by stimulating nicotinic acetylcholine receptors (nAChRs) on the cell bodies of mesolimbic dopamine neurons (Corrigall et al, 1994; DiChiara, 2000; Nisell et al, 1994; Stolerman and Shoaib, 1991; Watkins et al, 2000). The importance of dopamine in the reinforcing effects of nicotine was initially suggested by the fact that dopamine $\mathrm{D}_{1}$-like and $\mathrm{D}_{2}$-like receptor antagonists, as well as nicotinic receptor antagonists, reduced nicotine selfadministration in preclinical studies (Pierce and Kumaresan, 2006; Watkins et al, 2000). Dopamine $\mathrm{D}_{3}$ and $\mathrm{D}_{4}$ receptors also appear to modulate the abuse-related effects of both cocaine and nicotine as described below.

The extent to which simultaneous activation of dopamine release by nicotine and blockade of dopamine reuptake by cocaine may account for enhancement of the reinforcing effects of low doses of nicotine + cocaine in combination is unclear. However, evidence from microdialysis studies indicates that combinations of equipotent doses of cocaine + nicotine produce additive effects on dopamine release (Gerasimov et al, 2000; Sziraki et al, 1999; Zernig et al, 1997). In addition, overlapping patterns of fosrelated protein expression in rat brains after nicotine $(0.03 \mathrm{mg} / \mathrm{kg} / \mathrm{inj})$ and cocaine $(0.25 \mathrm{mg} / \mathrm{kg} / \mathrm{inj})$ self-adminis-
Table I Average Sedation Ratings ( \pm SEM) During Chronic Buspirone Treatment (0.32 or $0.56 \mathrm{mg} / \mathrm{kg} / \mathrm{h}$ ) When Monkeys Were Allowed to Self-Administer Various Doses of Cocaine and Nicotine or Cocaine + Nicotine Combinations $(0.0032 \mathrm{mg} / \mathrm{kg} / \mathrm{inj}$ Cocaine $+0.001 \mathrm{mg} / \mathrm{kg} / \mathrm{inj}$ Nicotine, or $0.0032 \mathrm{mg} / \mathrm{kg} / \mathrm{inj}$ Cocaine $+0.0032 \mathrm{mg} / \mathrm{kg} / \mathrm{inj}$ Nicotine)

Sedation rates during buspirone treatment

\begin{tabular}{|c|c|c|c|c|}
\hline \multirow[t]{2}{*}{ Drug } & \multicolumn{2}{|c|}{ First 3 days } & \multicolumn{2}{|c|}{ Last 3 days } \\
\hline & $\begin{array}{l}0.32 \mathrm{mg} / \\
\mathrm{kg} / \mathrm{h}\end{array}$ & $\begin{array}{l}0.56 \mathrm{mg} / \\
\mathrm{kg} / \mathrm{h}\end{array}$ & $\begin{array}{c}0.32 \mathrm{mg} / \\
\mathrm{kg} / \mathrm{h}\end{array}$ & $\begin{array}{c}0.56 \mathrm{mg} / \\
\mathrm{kg} / \mathrm{h}\end{array}$ \\
\hline Cocaine & $0.65(0.18)$ & $0.93(0.21)$ & $0.22(0.11)$ & $0.22(0.10)$ \\
\hline Nicotine & $0.80(0.11)$ & $1.15(0.16)$ & $0.20(0.08)$ & $0.27(0.09)$ \\
\hline $\begin{array}{l}\text { Cocaine }+0.001 \\
\text { Nicotine }\end{array}$ & $0.40(0.24)$ & $1.07(0.52)$ & $0.00(0.00)$ & $0.47(0.23)$ \\
\hline $\begin{array}{l}\text { Cocaine }+0.003 \\
\text { Nicotine }\end{array}$ & $1.06(0.43)$ & $1.27(0.49)$ & $0.2(0.2)$ & $0.67(0.32)$ \\
\hline
\end{tabular}

Cocaine and nicotine data from various doses of cocaine or nicotine were collapsed to ease comparison with the cocaine + nicotine combinations. All sedation ratings during saline treatment were 0 (no sedation). Sedation was scored as: $0=$ no observable sedation, alert to environment; $\mid=$ mildly sedated, quieter than usual, but reaches for food treats; $2=$ moderately sedated, does not reach for food treats, but does respond to noise in the room; $3=$ heavily sedated, lying on case floor, no response to experimenter. Cocaine data are from Mello et al, 2012. These data are based on 4-5 monkeys.

tration, but not after saline-control self-administration, were interpreted to suggest that there is a common anatomical substrate for cocaine and nicotine addiction (Pich et al, 1997). There is considerable overlap between nAChRs and mesolimbic dopamine neurons, and nicotinic receptor distribution is very similar in human and monkey brain (Gotti and Clementi, 2004; Gotti et al, 2007; Han et al, $2000,2003)$. Of the receptor subtypes that comprise nAChRs, the $\alpha 4 \beta 2$ receptor is one of the most abundant, 
and appears to be one important modulator of the reinforcing effects of nicotine (Benowitz, 2009; Picciotto et al, 1998; Rose, 2007; Watkins et al, 2000). There is general agreement that $\alpha 4 \beta 2$ nicotinic receptors are widely distributed in the cortex, thalamus, basal ganglia, and cerebellum in human and nonhuman primate brain (Gotti and Clementi, 2004; Gotti et al, 2007; Han et al, 2000; Paterson and Nordberg, 2000).

\section{Dopamine $\mathrm{D}_{3}$ and $\mathrm{D}_{4}$ Antagonist Interactions with Nicotine}

There has been increasing interest in the possible role of dopamine $\mathrm{D}_{3}$ receptor antagonists and partial agonists for the treatment of stimulant addiction (Newman et al, 2012). Buspirone has high affinity for dopamine $D_{3}$ and $D_{4}$ receptors, as well as for $\mathrm{D}_{2}$ receptors (Bergman et al, 2012). Radioligand binding studies showed that buspirone had the highest affinity for the dopamine $\mathrm{D}_{4}$ receptor and lower affinity for $\mathrm{D}_{3}$ and $\mathrm{D}_{2}$ receptors (Bergman et al, 2012). Live-cell functional assays indicated that buspirone antagonized dopamine activation of $\mathrm{D}_{3}$ and $\mathrm{D}_{4}$ receptors with similar potency, but had no agonist activity (Bergman et al, 2012). Buspirone's active metabolites (6-hydroxylbuspirone and 5-hydroxybuspirone; Dockens et al, 2006) also appear to have $\mathrm{D}_{3}$ and $\mathrm{D}_{4}$ antagonist activity (Bergman et al, 2012; Newman et al, 2012). The contribution of these long-acting metabolites to buspirone's interactions with cocaine and nicotine has not been determined, but plasma concentrations of 6-hydroxybuspirone, were about 40-fold higher than buspirone over a wide dose range (Dockens et al, 2006). An intriguing literature suggests that $D_{3}$ antagonists may be one important mediator of cocaine's abuse-related effects (see for review Heidbreder et al, 2005; Heidbreder and Newman, 2010; Le Foll et al, 2000, 2005a; Newman et al, 2005, 2009, 2012). The mechanisms by which buspirone selectively reduced nicotine and nicotine + cocaine selfadministration are unknown, and probably reflect an interaction between buspirone's activity at dopamine and $5-\mathrm{HT}_{1 \mathrm{~A}}$ receptors. It is interesting to consider the possible contribution of $\mathrm{D}_{3}$ antagonist effects to buspirone's reduction of self-administration of nicotine alone and nicotine + cocaine combinations, as well as cocaine alone in our previous studies (Bergman et al, 2012; Mello et al, 2012).

There is also evidence that $\mathrm{D}_{3}$ antagonists can modify some of the abuse-related properties of nicotine. For example, the $\mathrm{D}_{3}$ antagonist SB-277011A (1-12 mg/kg) dose-dependently reduced nicotine-enhanced and methamphetamine-enhanced brain stimulation reward (Pak et al, 2006; Spiller et al, 2008). However, as noted earlier, this $\mathrm{D}_{3}$ antagonist has been more effective in reducing nicotine reinstatement than nicotine self-administration in rats. When nicotine self-administration $(0.03 \mathrm{mg} / \mathrm{kg} / \mathrm{inj})$ was maintained on a fixed ratio 2 (FR 2), low doses of SB-277011A (3-10 mg/kg) had no effect (Andreoli et al, 2003). When nicotine self-administration at the same unit dose $(0.03 \mathrm{mg} / \mathrm{kg} / \mathrm{inj})$ was maintained on a progressive ratio schedule that required completion of an increasing number of responses (eg, 7, 10, 14-77) for each injection or food pellet, a higher dose of SB-277011A $(56 \mathrm{mg} / \mathrm{kg})$ significantly reduced nicotine self-administra- tion, with minimal effects on food-maintained responding (Ross et al, 2007). Lower doses of SB-277011A (3, 10, $30 \mathrm{mg} /$ $\mathrm{kg}$ ) had no significant effect on nicotine- or foodmaintained responding (Ross et al, 2007). In another study, SB-277011A (1-10 mg/kg) did not alter nicotine selfadministration $(0.03 \mathrm{mg} / \mathrm{kg} / \mathrm{inj})$ maintained on an FR 5 schedule, but blocked cue-induced reinstatement of extinguished nicotine-maintained responding (Khaled et al, 2010). Similar results were reported for the dopamine $D_{4}$ antagonist L-745 870 (Yan et al, 2012). These data converge to suggest that dopamine $\mathrm{D}_{3}$ receptors may be less involved in mediation of the reinforcing effects of nicotine, than in the other abuse-related behaviors. Some investigators have concluded that dopamine $\mathrm{D}_{3}$ receptor antagonists may be valuable for the treatment of relapse to nicotine seeking, but are less likely to substitute for nicotine or to attenuate withdrawal signs and symptoms (Le Foll et al, 2007a).

The discrepancy between these findings in rats and our present findings in rhesus monkeys may be simply a species difference. It is well established that there are significant differences in anatomy, physiology, and neurochemistry between rhesus monkeys and rats, and that monkeys are most similar to humans (Weerts et al, 2007). However, species comparisons are limited by the fact that we did not study the effects of a $D_{3}$ receptor antagonist on nicotine self-administration, and we did not study nicotine reinstatement in rhesus monkeys. We hypothesize that buspirone's $\mathrm{D}_{3}$ antagonist effects may have contributed to its effects on nicotine and cocaine self-administration based on an extensive literature described earlier. In studies where the $\mathrm{D}_{3}$ antagonist SB-277011A selectively reduced nicotine self-administration by rodents (Ross et al, 2007), a number of procedural differences further complicate comparisons. We were unable to locate studies of buspirone's interactions with the reinforcing properties of nicotine in any species.

Buspirone also acts as a 5- $\mathrm{HT}_{1 \mathrm{~A}}$ partial agonist (NewmanTancredi et al, 1998; Wong et al, 2007). However, the $5-\mathrm{HT}_{1 \mathrm{~A}}$ partial agonist, geperone, did not appear to attenuate the discriminative stimulus or reinforcing effects of cocaine (Callahan and Cunningham, 1997; Gold and Balster, 1992). These data were interpreted to suggest that 5$\mathrm{HT}_{1 \mathrm{~A}}$ activity may have minimal effects on the abuse-related effects of cocaine (Gold and Balster, 1992). Although it is unlikely that $5-\mathrm{HT}_{1 \mathrm{~A}}$ activity was an important factor in buspirone's interactions with nicotine and cocaine selfadministration, 5- $\mathrm{HT}_{1 \mathrm{~A}}$ effects are complex and influence stimulant abuse under some conditions (Homberg et al, 2004; Muller et al, 2007).

\section{Translational Implications of Buspirone's Reduction of Nicotine and Nicotine + Cocaine Self-Administration}

At present, no dopamine $\mathrm{D}_{3}$ receptor antagonists are available for clinical use. However, buspirone is FDAapproved for the treatment of anxiety, and this will greatly facilitate examining its clinical effectiveness in persons with dual addiction to nicotine and cocaine. Cocaine abusers are often heavy smokers, and a medication that could safely reduce both cocaine abuse and cigarette smoking with minimal side effects would be clinically useful. Clinical laboratory studies also have consistently shown interactions 
between nicotine and cocaine. In cocaine-dependent cigarette smokers, an acute dose of transdermal nicotine ( $44 \mathrm{mg}$ ) enhanced reports of cocaine craving induced by crack cocaine-related visual cues and paraphernalia, whereas placebo patches had no effect (Reid et al, 1998). In a subsequent study of cue-induced cocaine craving, a nicotine antagonist, mecamylamine reduced reports of craving in comparison with placebo (Reid et al, 1999). As noted earlier, cocaine users smoke more cigarettes during cocaine use (Roll et al, 1996, 1997) and smokers use more cocaine than non-smokers (Budney et al, 1993). Clinical studies of buspirone's effects on cigarette smoking in non-cocaine users have been inconsistent. Some reports indicate that buspirone significantly increased abstinence from cigarette smoking (Hilleman et al, 1992, 1994), but other studies found no significant effect of buspirone on smoking cessation and nicotine withdrawal symptoms (Farid and Abate, 1998; Schneider et al, 1996). Buspirone was most effective as a smoking cessation aid in high-anxiety smokers (Cinciripini et al, 1995). Although buspirone may not be equally effective in all smokers, these studies in rhesus monkeys suggest it may be useful for some smokers, especially those who concurrently abuse cocaine. The relative role of buspirone's dopamine $\mathrm{D}_{2}, \mathrm{D}_{3}$ and $\mathrm{D}_{4}$ activity in its interactions with nicotine and cocaine remains to be determined. However, a medication that can reduce nicotine, cocaine, and nicotine + cocaine self-administration in this rhesus monkey model of drug abuse, may be effective for treatment of dual addiction to nicotine and cocaine.

\section{ACKNOWLEDGEMENTS}

This study was supported in part by grants R01-DA02519 and R01-DA026892 (NK Mello, PI) from the National Institute on Drug Abuse, NIH. We thank Meredith Mahnke, Sherilyn Pappal, and Olga Smirnova for excellent technical assistance.

\section{DISCLOSURE}

The authors declare no conflict of interest.

\section{REFERENCES}

Andreoli M, Tessari M, Pilla M, Valerio E, Hagan JJ, Heidbreder CA (2003). Selective antagonism at dopamine D3 receptors prevents nicotine-triggered relapse to nicotine-seeking behavior. Neuropsychopharmacology 28: 1272-1280.

Bechtholt AJ, Mark GP (2002). Enhancement of cocaine-seeking behavior by repeated nicotine exposure in rats. Psychopharmacology (Berl) 162: 178-185.

Benowitz NL (2009). Pharmacology of nicotine: addiction, smoking-induced disease, and therapeutics. Annu Rev Pharmacol Toxicol 49: 57-71.

Bergman J, Roof RA, Furman CA, Conroy JL, Mello NK, Sibley DR et al (2012). Modification of cocaine self-administration by buspirone (Buspar $(\mathbb{R})$ : potential involvement of D3 and D4 dopamine receptors. Int J Neuropsychopharmacol 25: 1-14.

Budney AJ, Higgins ST, Hughes JR, Bickel WK (1993). Nicotine and caffeine use in cocaine-dependent individuals. J Subst Abuse 5: 117-130.
Butelman ER, Harris TJ, Kreek MJ (1999). Effects of E-2078, a stable dynorphin A(1-8) analog, on sedation and serum prolactin levels in rhesus monkeys. Psychopharmacology (Berl) 147: 73-80.

Callahan PM, Cunningham KA (1997). Modulation of the discriminative stimulus properties of cocaine: comparison of the effects of fluoxetine with 5-HT1A and 5-HT1B receptor agonists. Neuropharmacology 36: 373-381.

CDC (2002). Cigarette smoking among adults-United States. 2000. Morb Mortal Wkly Rep 51: 642-645.

CDC (2004). Adult cigarette smoking in the United States: current estimates. National Center for Chronic Disease Prevention and Health Promotion Tobacco Information and Prevention Source (TIPS) 15: 20-58.

Centers for Disease Control and Prevention (CDC) (2005). Annual smoking-attributable mortality, years of potential life lost and productivity losses-United States, 1997-2001. MMWR Morb Mortal Wkly Rep 54: 625-628.

Cinciripini PM, Lapitsky L, Seay S, Wallfisch A, Meyer WJI, Van Vunakis H (1995). A placebo-controlled evaluation of the effects of buspirone on smoking cessation: Differences between high- and low-anxiety smokers. J Clin Pharmacol 15: 182-191.

Corrigall WA, Coen KM, Adamson KL (1994). Self-administered nicotine activates the mesolimbic dopamine system through the ventral tegmental area. Brain Res 653: 278-284.

DiChiara G (2000). Role of dopamine in the behavioural actions of nicotine related to addiction. Eur J Pharmacol 393: 295-314.

Dockens RC, Salazar DE, Fulmore IE, Wehling M, Arnold ME, Croop R (2006). Pharmacokinetics of a newly identified active metabolite of buspirone after administration of buspirone over its therapeutic dose range. J Clin Pharmacol 46: 1308-1312.

Dockens RC, Tran AQ, Zeng J, Croop R (2007). Pharmacokinetics of 6-hydroxybuspirone and its enantiomers administered individually or following buspirone administration in humans. Biopharm Drug Dispos 28: 393-402.

Farid P, Abate MA (1998). Buspirone use for smoking cessation. Ann Pharmacother 32: 1362-1364.

Fivel PA (2011). Computer-controlled drug doses for IV drug selfadministration. Exp Clin Psychopharmacol 19: 131-133.

Freeman KB, Woolverton WL (2009). Self-administration of cocaine and nicotine mixtures by rhesus monkeys. Psychopharmacology (Berl) 207: 99-106.

Gammans RE, Mayol RF, LaBudde JA (1986). Metabolism and disposition of buspirone. Am J Med 80: 41-51.

Gerasimov MR, Franceschi M, Volkow ND, Rice O, Schiffer WK, Dewey SL (2000). Synergistic interactions between nicotine and cocaine or methylphenidate depend on the dose of dopamine transporter inhibitor. Synapse 38: 432-437.

Gold LH, Balster RL (1992). Effects of buspirone and gepirone on i.v. cocaine self-administration in rhesus monkeys. Psychopharmacology (Berl) 108: 289-294.

Goldberg SR, Spealman RD, Goldberg DM (1981). Persistent behavior at high rates maintained by intravenous self-administration of nicotine. Science 214: 573-575.

Gotti C, Clementi F (2004). Neuronal nicotinic receptors: from structure to pathology. Prog Neurobiol 74: 363-396.

Gotti C, Moretti M, Gaimarri A, Zanardi A, Clementi F, Zoli M (2007). Heterogeneity and complexity of native brain nicotinic receptors. Biochem Pharmacol 74: 1102-1111.

Han ZY, Le Novere N, Zoli M, Hill JAJ, Champtiaux N, Changeux JP (2000). Localization of nAChR subunit mRNAs in the brain of Macaca mulatta. Eur J Neurosc 12: 3664-3674.

Han ZY, Zoli M, Cardona A, Bourgeois JP, Changeux JP, Le Novere $\mathrm{N}$ (2003). Localization of $\left[{ }^{3} \mathrm{H}\right]$ Nicotine, $\left[{ }^{3} \mathrm{H}\right]$ Cytisine, $\left[{ }^{3} \mathrm{H}\right]$ Epibatidine, and $\left[{ }^{125} \mathrm{I}\right] \mathrm{a}$-Bungarotoxin binding sites in the brain of Macaca mulatta. J Comp Neurol 461: 49-60.

Heidbreder CA, Gardner EL, Xi Z-X, Thanos PK, Mugnaini M, Hagan JJ et al (2005). The role of central dopamine D3 receptors 
in drug addiciton: a review of pharmacological evidence. Brain Res Rev 49: 77-105.

Heidbreder CA, Newman AH (2010). Current perspectives on selective dopamine $D_{3}$ receptor antagonists as pharmacotherapeutics for addictions and related disorders. Ann NY Acad Sci 1187: 4-34.

Henningfield JE, Fant RV, Buchhalter AR, Stitzer ML (2005). Pharmacotherapy for nicotine dependence. CA Cancer J Clin 55: 281-299.

Hilleman DE, Mohiuddin SM, Del Core MG, Sketch Sr MH (1992). Effect of buspirone on withdrawal symptoms associated with smoking cessation. Arch Intern Med 152: 350-352.

Hilleman DE, Mohiuddin SM, Delcore MG (1994). Comparison of fixed-dose transdermal nicotine, tapered-dose transdermal nicotine, and buspirone in smoking cessation. J Clin Pharmacol 34: 222-224.

Homberg JR, Arends B, Wardeh G, Raaso HS, Schoffelmeer AN, de Vries TJ (2004). Individual differences in the effects of serotonergic anxiolytic drugs on the motivation to self-administer cocaine. Neuroscience 128: 121-130.

Horger BA, Giles MK, Schenk S (1992). Preexposure to amphetamine and nicotine predisposes rats to self-administer a low dose of cocaine. Psychopharmacology (Berl) 107: 271-276.

ILAR-NRC (1996). Guide for the Care and Use of Laboratory AnimalsNational Academy Press: Washington, DC125.

Khaled MATM, Araki KF, Li B, Coen KM, Marinelli PW, Varga J et al (2010). The selective dopamine $\mathrm{D}_{3}$ receptor antagonist SB277011A, but not the partial agonist BP 897, blocks cue-induced reinstatement of nicotine-seeking. Int J Neuropsychopharmacol 13: $181-190$.

Kuhar MJ, Ritz MC, Boja JW (1991). The dopamine hypothesis of the reinforcing properties of cocaine. TINS 14: 299-302.

Kula NS, Baldessarini RJ, Kebabian JW, Neumeyer JL (1994). $\mathrm{S}-(+)$-aporphines are not selective for human D3 dopamine receptors. Cell Mol Neurobiol 14: 185-191.

Le Foll B, Goldberg SR, Sokoloff P (2005a). D3 receptor and drug dependence: effects on reward or beyond? Neuropharmacology 49: 525-541.

Le Foll B, Goldberg SR, Sokoloff P (2007a). Dopamine D3 receptor ligands for the treatment of tobacco dependence. Expert Opin Investig Drugs 16: 45-57.

Le Foll B, Schwartz J-C, Sokoloff P (2000). Dopamine D3 receptor agents as potential new medications for drug addiction. Eur Psychiatry 15: 140-146.

Le Foll B, Sokoloff P, Stark H, Goldberg SR (2005b). Dopamine $\mathrm{D}_{3}$ ligands block nicotine-induced conditioned place preferences through a mechanism that does not involve discriminativestimulus or antidepressant-like effects. Neuropsychopharmacol 30: $720-730$.

Le Foll B, Wertheim C, Goldberg SR (2007b). High reinforcing efficacy of nicotine in non-human primates. PloS One 2: e230.

Line SW (1987). Environmental enrichment for laboratory primates. JAVMA 190: 854-859.

Mello NK (2005). Marian W. Fischman Memorial Lecture (2004). Evaluation of drug abuse treatment medications: Concordance between clinical and preclinical studies. In: Dewey WL (eds). Problems of Drug Dependence 2004: Proceedings of the 66th Annual Scientific Meeting, The College on Problems of Drug Dependence, Inc. US Department of Health and Human Services, National Institutes of Health: Bethesda, MD, pp 82-104.

Mello NK, Fivel PA, Kohut SJ, Bergman J (2012). Effects of chronic buspirone treatment on cocaine self-administration. Neuropsychopharmacology 38: 455-467.

Mello NK, Negus SS (1996). Preclinical evaluation of pharmacotherapies for treatment of cocaine and opiate abuse using drug self-administration procedures. Neuropsychopharmacology 14: 375-424.
Mello NK, Negus SS, Lukas SE, Mendelson JH, Sholar JW, Drieze JM (1995). A primate model of polydrug abuse: Cocaine and heroin combinations. J Pharmacol Exp Ther 274: 1325-1337.

Mello NK, Newman JL (2011). Discriminative and reinforcing stimulus effects of nicotine, cocaine, and cocaine + nicotine combinations in rhesus monkeys. Exp Clin Psychopharmacol 19: 203-214.

Muller CP, Carey RJ, Huston JP, De Souza Silva MA (2007). Serotonin and psychostimulant addiction: focus on $5-\mathrm{HT}_{1 \mathrm{~A}^{-}}$ receptors. Prog Neurobiol 81: 133-178.

Negus SS, Mello NK (2003a). Effects of chronic d-amphetamine treatment on cocaine- and food-maintained responding under a progressive-ratio schedule in rhesus monkeys. Psychopharmacol 167: 324-332.

Negus SS, Mello NK (2003b). Effects of chronic $d$-amphetamine treatment on cocaine- and food-maintained responding under a second-order schedule in rhesus monkeys. Drug Alc Depend 70: 39-52.

Newman AH, Blaylock BL, Nader MA, Bergman J, Sibley DR, Skolnick P (2012). Medication discovery for addiction: Translating the dopamine D3 receptor hypothesis. Biochem Pharmacol 84: 992-890.

Newman AH, Grundt P, Cyriac G, Deschamps JR, Taylor M, Kumar $\mathrm{R}$ et al (2009). N-(4-(4-(2,3-Dichloro-or2-methoxyphenyl)piperazin-1-yl)butyl)heterobiarylcarboxamides with functionalized linking chains as high affinity and enantioselective $\mathrm{D}_{3}$ receptor antagonists. J Med Chem 52: 2559-2570.

Newman AH, Grundt P, Nader MA (2005). Dopamine D3 receptor partial agonists and antagonists as potential drug abuse therapeutic agents. J Med Chem 48: 3663-3679.

Newman-Tancredi A, Gavaudan S, Conte C, Chaput C, Touzard M, Verriele L et al (1998). Agonist and antagonist actions of antipsychotic agents at 5-HT1A receptors: a [35S]GTPgammaS binding study. Eur J Pharmacol 355: 245-256.

Nisell M, Nomikos GG, Svensson TH (1994). Systemic nicotineinduced dopamine release in the rat nucleus accumbens is regulated by nicotinic receptors in the ventral tegmental area. Synapse 16: 36-44.

Pak AC, Ashby CR, Heidbreder CA, Pilla M, Gilbert JG, Xi X-Z et al (2006). The selective dopamine D3 receptor antagonist SB-277011A reduces nicotine-enhanced brain reward and nicotine-paired environmental cue functions. Int J Neuropsychopharmacol 9: 1-18.

Paterson D, Nordberg A (2000). Neuronal nicotinic receptors in the human brain. Prog Neurobiol 61: 75-111.

Picciotto MR, Zoli M, Rimondini R, Lena C, Marubio LM, Pich EM et al (1998). Acetylcholine receptors containing the beta2 subunit are involved in the reinforcing properties of nicotine. Nature 391: 173-177.

Pich EM, Pagliusi SR, Tessari M, Talabot-Ayer D, Hooft van Huijsduijnen R, Chiamulera C (1997). Common neural substrates for the addictive properties of nicotine and cocaine. Science 275: 83-86.

Pierce RC, Kumaresan V (2006). The mesolimbic dopamine system: the final common pathway for the reinforcing effect of drugs of abuse? Neurosci Biobehav Rev 30: 215-238.

Reavill C, Taylor SG, Wood MD, Ashmeade T, Austin NE, Avenell $\mathrm{KY}$ et al (2000). Pharmacological actions of a novel, highaffinity, and selective human dopamine $\mathrm{D}_{3}$ receptor antagonist, SB-277011A. J Pharmacol Exp Ther 294: 1154-1165.

Reid MS, Mickalian JD, Delucchi KL, Berger SP (1999). A nicotine antagonist, mecamylamine, reduces cue-induced cocaine craving in cocaine-dependent subjects. Neuropsychopharmacology 20: 297-307.

Reid MS, Mickalian JD, Delucchi KL, Hall SM, Berger SP (1998). An acute dose of nicotine enhances cue-induced cocaine craving. Drug Alc Depend 49: 95-104. 
Ritz MC, Lamb RJ, Goldberg SR, Kuhar MJ (1987). Cocaine receptors on dopamine transporters are related to self-administration of cocaine. Science 237: 1219-1223.

Ritz MC, Lamb RJ, Goldberg SR, Kuhar MJ (1988). Cocaine selfadministration appears to be mediated by dopamine uptake inhibition. Prog Neuropsychopharmacol Biol Psychiatry 12: 233-239.

Roll JM, Higgins ST, Budney AJ, Bickel WK, Badger GJ (1996). A comparison of cocaine-dependent cigarette smokers and nonsmokers on demographic, drug use and other characteristics. Drug Alcohol Depend 40: 195-201.

Roll JM, Higgins ST, Tidey J (1997). Cocaine use can increase cigarette smoking: evidence from laboratory and naturalistic settings. Exp Clin Psychopharmacol 5: 263-268.

Rose JE (2007). Multiple brain pathways and receptors underlying tobacco addiction. Biochem Pharmacol 74: 1263-1270.

Ross JT, Corrigall WA, Heidbreder CA, LeSage MG (2007). Effects of the selective dopamine D3 receptor antagonist SB-277011A on the reinforcing effects of nicotine as measured by a progressiveratio schedule in rats. Eur J Clin Pharmacol 559: 173-179.

Schneider NG, Olmstead RE, Steinberg C, Sloan K, Daims RM, Brown HV (1996). Efficacy of buspirone in smoking cessation: a placebo-controlled trial. Clin Pharmacol Ther 60: 568-575.

Spiller K, Xi XZ, Peng XQ, Newman AH, Ashby CRJ, Heidbreder C et al (2008). The selective dopamine D3 receptor antagonists SB277011A and NGB 2904 and the putative partial D3 receptor agonist BP-897 attenuate methamphetamine-enhanced brain stimulation reward in rats. Psychopharmacology (Berl) 196: 533-542.

Stemp G, Ashmeade T, Branch CL, Hadley MS, Hunter AJ, Johnson $\mathrm{CN}$ et al (2000). Design and synthesis of trans-N-[4-[2-(6-cyano1,2,3, 4-tetrahydroisoquinolin-2-yl)ethyl]cyclohexyl]-4-quinolinecarboxamide (SB-277011): A potent and selective dopamine $\mathrm{D}(3)$ receptor antagonist with high oral bioavailability and CNS penetration in the rat. $J$ Med Chem 43: 1878-1885.
Stolerman IP, Shoaib M (1991). The neurobiology of tobacco addiction. Trends Pharmacol Sci 12: 467-473.

Sziraki I, Sershen H, Benuck M, Hashim A, Laitha A (1999). Differences in receptor system participation between nicotineand cocaine-induced dopamine overflow in nucleus accumbens. NY Acad Sci 877: 800-802.

Tallman F, Primus RJ, Brodbeck R, Cornfield L, Meade R, Woodruff K et al (1997). I. NGD 94-1: Identification of a novel, high-affinity antagonist at the human dopamine D4 receptor. J Pharmacol Exp Ther 282: 1011-1019.

Watkins SS, Koob GF, Markou A (2000). Neural mechanisms underlying nicotine addiction: acute positive reinforcement and withdrawal. Nicotine Tob Res 2: 19-37.

Weerts EM, Fantegrossi WE, Goodwin AK (2007). The value of nonhuman primates in drug abuse research. Exp Clin Psychopharmacol 15: 309-327.

Winhusen T, Brady KT, Stitzer M, Woody G, Lindblad R, Kropp F et al (2012). Evaluation of buspirone for relapseprevention in adults with cocaine dependence: an efficacy trial conducted in the real world. Contemp Clin Trials 33: 993-1002.

Wong H, Dockens RC, Pajor L, Yeola S, Grace JEJ, Stark AD et al (2007). 6-hydroxybuspirone is a major active metabolite of buspirone: assessment of pharmacokinetics and 5-hydroxytryptamine $1 \mathrm{~A}$ receptor occupancy in rats. Drug Metab Dispos 35: 1387-1392.

Yan Y, Pushparaj A, Le Strat Y, Gamaleddin I, Barnes C, Justinova $\mathrm{Z}$ et al (2012). Blockade of dopamine $\mathrm{D} 4$ receptors attenuates reinstatement of extinguished nicotine-seeking behavior in rats. Neuropsychopharmacology 37: 685-696.

Zernig G, O'Laughlin IA, Fibiger HC (1997). Nicotine and heroin augment cocaine-induced dopamine overflow in nucleus accumbens. Eur J Pharmacol 337: 1-10. 